\title{
RESEARCH
}

Open Access

\section{Retention of different temporary cements tested on zirconia crowns and titanium abutments in vitro}

Felix Dähne ${ }^{1}$, Heike Meißner ${ }^{2}$, Klaus Böning ${ }^{2}$, Christin Arnold ${ }^{3}$, Ralf Gutwald ${ }^{4}$ and Elisabeth Prause ${ }^{5^{*}}$ (D)

\begin{abstract}
Purpose: The aim of the present study was to examine the retention force of monolithic zirconia copings cemented with various temporary cements on implant abutments in vitro.
\end{abstract}

Methods: Sixty exercise implants with pre-screwed implant abutments were embedded in resin. Subsequently, 60 CAD/CAM manufactured zirconia copings were divided into three main groups [Harvard Implant Semi-permanent (HAV), implantlink semi Forte (IMP), Temp Bond NE (TBNE)]. The zirconia copings were cemented on the implant abutments and loaded with $35 \mathrm{~N}$. Specimens were stored in distilled water $\left(37^{\circ} \mathrm{C}\right)$ for $24 \mathrm{~h}$. Half of the test specimens of each group were subjected to a thermocycling (TC) process. Retention force was measured in a universal testing machine. Using magnifying glasses, the fracture mode was determined. Statistical analysis was performed applying the Kruskal-Wallis test, the post hoc test according to Dunn-Bonferroni and a chi-square test of independence.

Results: Without TC, IMP showed the highest retention of the three temporary luting agents (100.5 $\pm 39.14 \mathrm{~N})$. The measured retention forces of IMP were higher than those of HAV $(45.78 \pm 15.66 \mathrm{~N})$ and TBNE $(61.16 \pm 20.19 \mathrm{~N})$. After TC, retention was reduced. IMP showed the greatest retentive strength (21.69 $\pm 13.61 \mathrm{~N}$, three fail outs). HAV and TBNE showed pull-off forces of similar magnitude (17.38 $\pm 12.77 \mathrm{~N}$ and $16.97 \pm 12.36 \mathrm{~N}$, two fail outs). The fracture mode analysis showed different results regarding the tested cements before and after TC (facture type before/after TC): IMP $(I I I+I I / I I), H A V(I / I)$ and TBNE (III/III). There were clear differences of the fracture modes regarding the examination before and after TC.

Conclusions: Within the limits of this study, IMP showed the highest pull-off forces under the chosen test conditions. All three temporary luting agents showed lower retention forces after TC. Retention values in the individual cement classes were very heterogeneous. Easy cement removal in the crown lumen favours the dominance of adhesive cement fractures on the abutment and adhesive/cohesive cement fractures on the abutment with HAV appears advantageous in case of recementation of the superstructure.

Keywords: Implantology, Zirconia crowns, Titanium, Retention, Temporary cements, Fracture mode analysis

\footnotetext{
* Correspondence: elisabeth.prause@charite.de

${ }^{5}$ Department of Prosthodontics, Geriatric Dentistry and Craniomandibular Disorders, University Charité Berlin, Aßmannshauser Str. 4-6, 14197 Berlin, Germany

Full list of author information is available at the end of the article
}

\section{Springer Open}

(c) The Author(s). 2021 Open Access This article is licensed under a Creative Commons Attribution 4.0 International License, which permits use, sharing, adaptation, distribution and reproduction in any medium or format, as long as you give appropriate credit to the original author(s) and the source, provide a link to the Creative Commons licence, and indicate if changes were made. The images or other third party material in this article are included in the article's Creative Commons licence, unless indicated otherwise in a credit line to the material. If material is not included in the article's Creative Commons licence and your intended use is not permitted by statutory regulation or exceeds the permitted use, you will need to obtain permission directly from the copyright holder. To view a copy of this licence, visit http://creativecommons.org/licenses/by/4.0/. 


\section{Background}

Implant-supported superstructures can be screw or cement retained. The advantage of cementation is that it is independent of the axial alignment of the implants. This is often indispensable for crowns and bridges. Furthermore, a loosening of the screw connection cannot lead to a fracture or loss of the implant screw $[1,2]$. However, the screw channel represents a weak point in terms of the material stability of the crown and its cleanability. Aesthetic limitations caused by any visible screw access may be eliminated with cementation [3] and a better framework fit has been described [1, 2, 4].

One of the advantages of screw fixation concern die periimplant tissue [5]. Thoma et al. found a lower pathogenic bacterial spectrum around screw-retained crowns than around cemented crowns on implants [4]. Furthermore, if the abutment screw becomes loose, it can be tightened again without any problems [6, 7]. In general, accessing and loosening or reattaching the implant-supported restoration is very easy with this option $[2,6,8,9]$.

Cemented restorations can be made retrievable by the use of semipermanent cements [10] which has become popular in recent years. Temporary cements have been successfully used for metal-ceramic restorations on titanium abutments for many years.

For semipermanent fixation on implants, it is required that the retention forces are in an area which, on the one hand, ensures undisturbed function under masticatory load and, at the same time, is stable in the aqueous environment of the oral cavity. On the other hand, it should allow the superstructure to be released when required without endangering the implant $[11,12]$. Some authors have considered retention forces in the range of 50-200 $\mathrm{N}$ to be necessary for this purpose [13-17]. If the superstructure is removed for whatever reason, cement residues remain on the abutment and in the crown lumen. These cement residues should be easily removable in order to avoid damaging either the abutment or the crown. A statement about the removability of cement residues could be derived from the fracture mode.

For this study, three established cements (Harvard Implant Semi-permanent ${ }^{\oplus}$, implantlink ${ }^{\ominus}$ semi Forte and Temp Bond ${ }^{\circ} \mathrm{NE}$ ) were selected and compared with respect to their retention force. The aim of the present study was to examine whether the retention

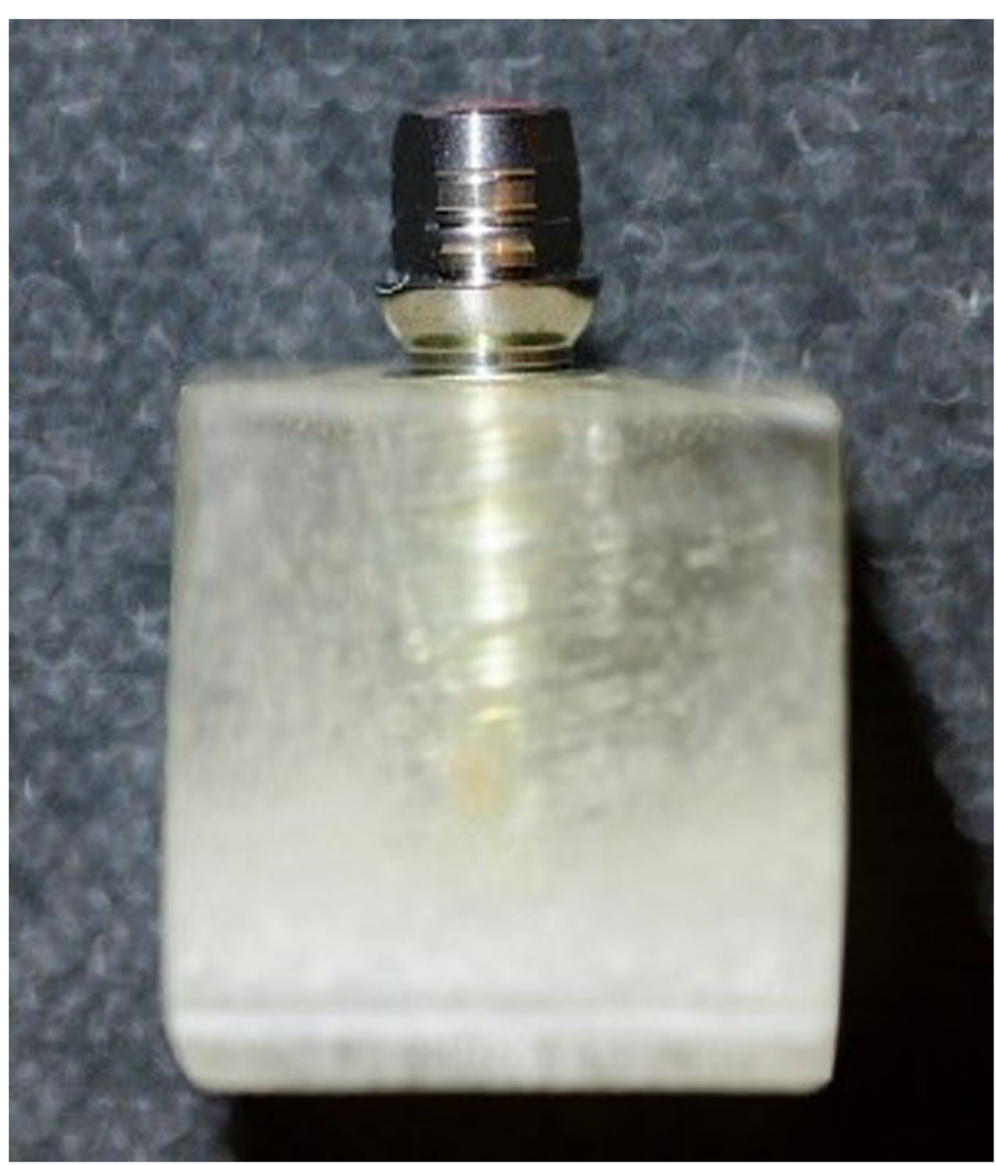

Fig. 1 Side view of an embedded specimen 
of these cements is comparable for the temporary cementation of monolithic zirconia superstructures. Furthermore, a fracture mode analysis should allow conclusions to be drawn about the removability of cement residues.

The following null hypotheses were tested:

1. The pull-off forces of the three temporary cements Harvard Implant Semi-permanent (HAV), implantlink semi Forte (IMP) and Temp Bond NE (TBNE) do not differ.

2. The fracture modes of the three temporary cements HAV, IMP and TBNE after removal do not differ.

\section{Methods}

In the study, 20 test specimens were produced per cement, of which 10 test specimens each were subjected to thermocycling. The number of samples was chosen based on other studies that addressed this issue [18-21]. Sixty implants (iSy", CAMLOG, Wimsheim, Germany) based on titanium with a length of $11 \mathrm{~mm}$ and diameters of 4.4 $\mathrm{mm}$ were used. These were pre-screwed with Camlog iSy ${ }^{\circ}$ titanium abutments (Camlog, Wimsheim, Germany) of the following geometry: diameter $4.0 \mathrm{~mm}$, prosthetic height $4.6 \mathrm{~mm}$, gingival height $1.6 \mathrm{~mm}$ and a cone angle of $3^{\circ}$ (Fig. 1). The cement gap size was set at $30 \mu \mathrm{m}$.
The abutments were provided with two horizontal circumferential grooves. Furthermore, the abutments were designed having three rotation lock areas to generate a rotation protection (Fig. 2).

All screw channels were closed with wax. Subsequently, the implants were embedded in a twocomponent resin (Paladur transparent, Kulzer, Hanau, Germany) (Fig. 3).

To fabricate the implant superstructure, the implant abutments were scanned with a desktop scanner (D900L, 3Shape A/S, Copenhagen, Denmark). With the help of a design software (Dental System Premium, 3Shape A/S, Copenhagen, Denmark), planning of the superstructure (wall thickness $0.5 \mathrm{~mm}$, cement film thickness $30 \mu \mathrm{m}$ ) was carried out in the form of a test specimen with lateral retaining wings (length $3 \mathrm{~mm}$, width $3 \mathrm{~mm}$, height $4 \mathrm{~mm}$ ) for subsequent clamping in the retaining bracket. The test specimens were milled from highly translucent zirconia discs (DD Bio $\mathrm{ZX}^{2}$ colour 98, Dental Direkt, Spenge, Germany) and then sintered at $1450{ }^{\circ} \mathrm{C}$ with a holding time of $120 \mathrm{~min}$. Subsequently, the test specimens were randomly distributed to three main groups (A-C).

Group A. Harvard Implant Semi-permanent: a dualcuring semipermanent cement based on multifunctional methacrylates and zinc.

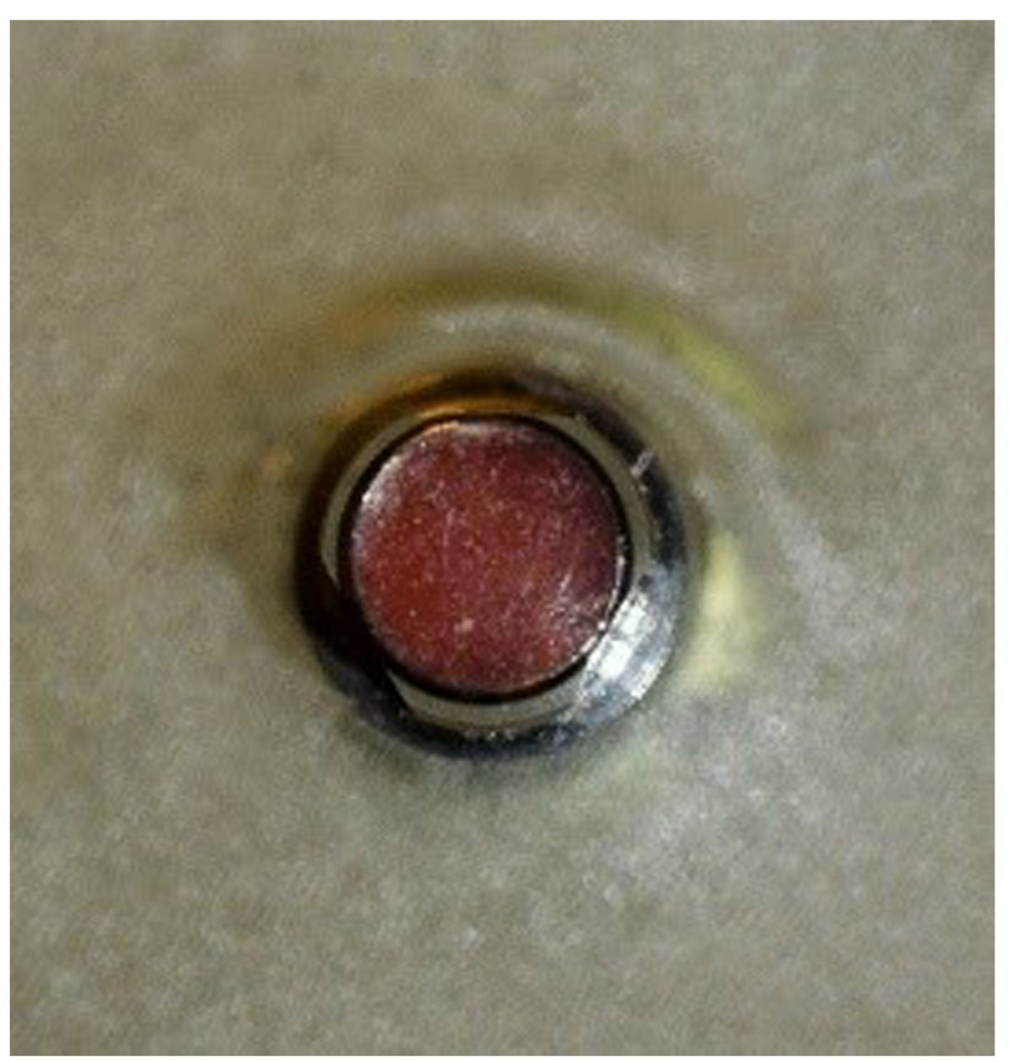

Fig. 2 Top view of the abutment with rotation lock 
Group B. implantlink ${ }^{\oplus}$ semi Forte: a dual-curing semipermanent cement based on meth- and urethane acrylate.

Group C. Temp Bond ${ }^{\oplus}$ NE: a eugenol-free semipermanent cement based on zinc oxide.

All implant abutments and the interior of the test specimens were cleaned with ethanol (70\%) before cementation and then dried with oil-free compressed air. Afterwards, the crown lumina of the test specimens were coated with a small amount of the respective temporary cement using a disposable brush and pressed onto the implant abutment as close as possible to the final position (= abutment shoulder). Immediately afterwards, the superstructure was pressure loaded with $35 \mathrm{~N}$ for $30 \mathrm{~s}$ in the universal testing machine TIRAtest 2720 (TIRA, Schalkau, Germany). The specimens were then stored at room temperature for $30 \mathrm{~min}$ until the complete setting reaction had occurred. After careful removal of excess cement residues, the specimens were stored for $24 \mathrm{~h}$ in distilled water at $37{ }^{\circ} \mathrm{C}$. Half of the test specimens of each group were then subjected to thermocycling (TC) of 6000 cycles $\left(5{ }^{\circ} \mathrm{C} / 55^{\circ} \mathrm{C}\right)$ with an exposure time of 27

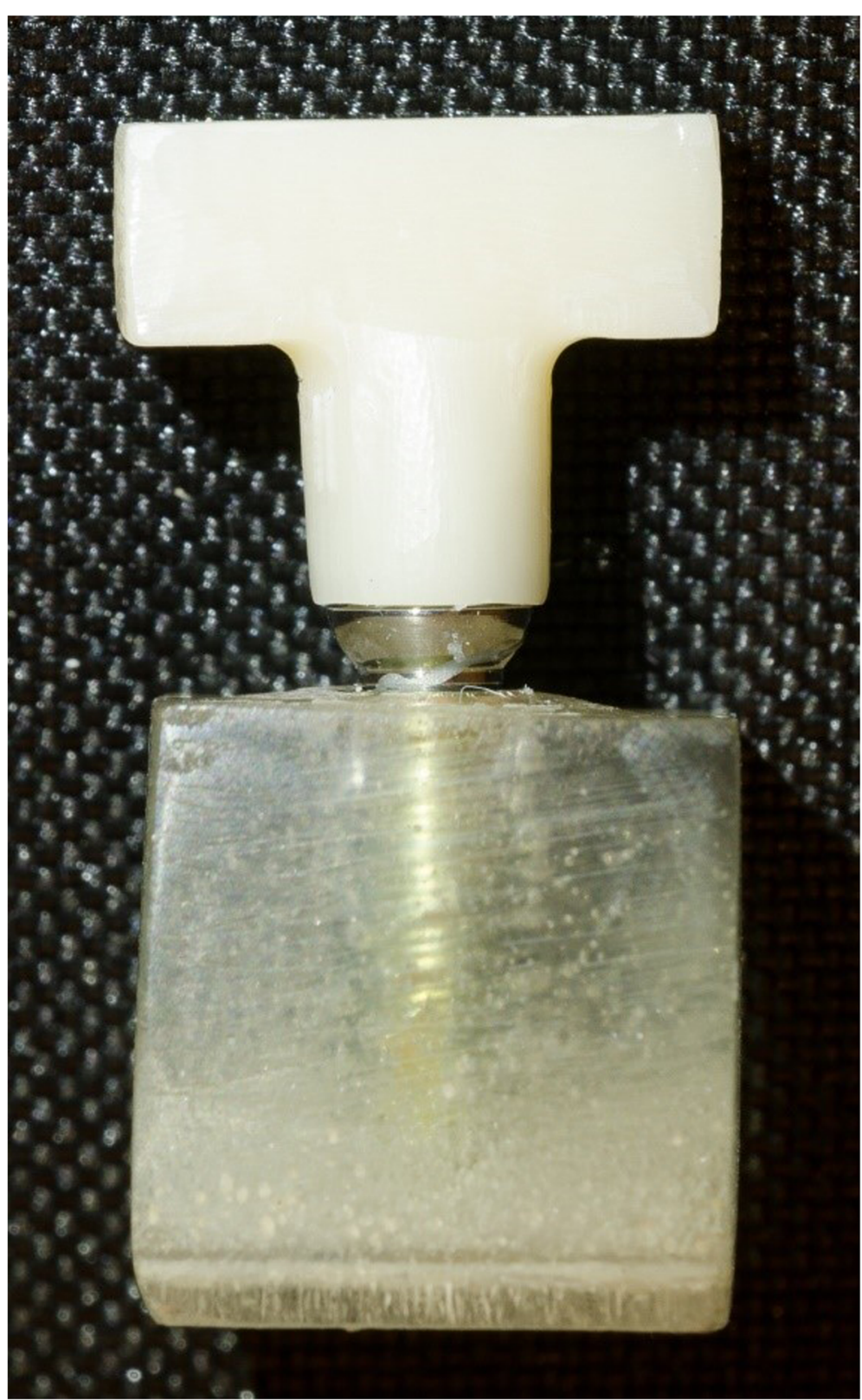

Fig. 3 Embedded implant with cemented superstructure 


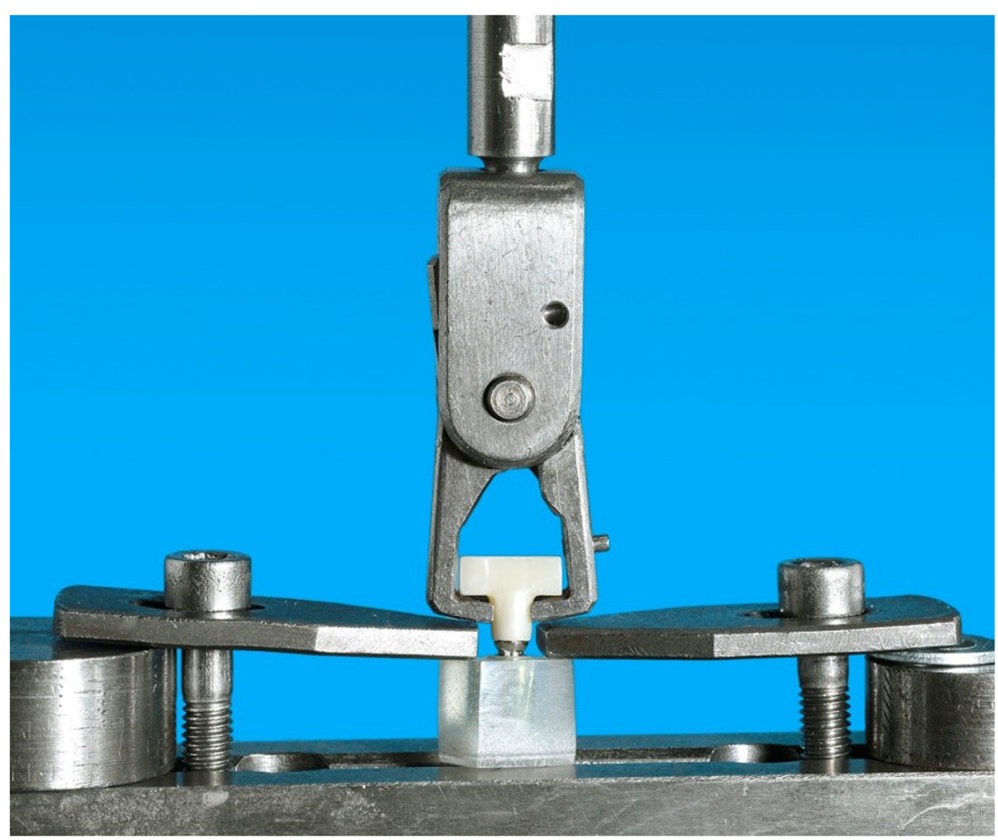

Fig. 4 Clamped test specimen with retaining clips positioned under the retaining wings

s per basin. The retention forces were determined with the universal testing machine TIRAtest 2720 (TIRA $\mathrm{GmbH}$, Schalkau, Germany). For this purpose, the resin blocks with the specimens embedded at a $90^{\circ}$ angle were fixed centrally in the platform of the testing machine with two opposing retaining wings. A holding bracket, which was attached centrally to the beam with the force sensor, was positioned under the holding wings of the specimens (Fig. 4). At a test speed of $1 \mathrm{~mm} / \mathrm{min}$, an axial tensile load was applied via the retaining wings until failure of the tension. The pull-off force was derived via the integrated load cell and recorded in a force-path diagram. Immediately after completion of the pull-off force measurement, the clamped test specimens were removed and classified with regards to their fracture modes with the aid of magnifying glasses at $\times 2.5$ magnification (Table 1, Fig. 7). Statistical significance was determined by means of the single-factor analysis of variance according to Kruskal-Wallis and the post hoc test according to Dunn-Bonferroni. The chi-square test of independence was used to compare breaking modes for temporary cements with and without TC.

\section{Results}

Without TC, the retention-force measurements (Table 2, Fig. 5) of the temporary cements showed significant differences between the groups $(p=0.0003$ in one-way ANOVA). The highest mean pull-off forces (100.5 \pm 39.14 $\mathrm{N})$ were measured for IMP and the lowest mean pull-off forces $(45.78 \pm 15.66 \mathrm{~N})$ for HAV $(p<0.001$; Bonferroni's multiple comparisons test; IMP vs. HAV). The measured pull-off forces of TBNE of $61.16 \pm 20.19 \mathrm{~N}$ ranged between the average pull-off forces of the other two cements

Table 1 Classification of the breaking modes and their characteristics

\begin{tabular}{|c|c|c|}
\hline Type & Breaking modes & Characteristics \\
\hline I & $\begin{array}{l}\text { Adhesive cement fracture on the } \\
\text { abutment }\end{array}$ & The abutment is largely cementless. The cement is completely in the crown lumen. \\
\hline$\|$ & $\begin{array}{l}\text { Adhesive/cohesive cement fracture } \\
\text { on the abutment }\end{array}$ & $\begin{array}{l}\text { There are cement residues on the abutment but not to an extent of the full thickness of the cement } \\
\text { film. The majority of the cement is located inside the crown. }\end{array}$ \\
\hline III & Cohesive cement fracture & $\begin{array}{l}\text { The abutment and the crown lumen are mainly covered with cement. The separation takes place } \\
\text { within the cement film. }\end{array}$ \\
\hline IV & $\begin{array}{l}\text { Adhesive cement fracture at the } \\
\text { crown }\end{array}$ & The crown lumen is largely free of cement. The cement is completely on the abutment. \\
\hline V & $\begin{array}{l}\text { Adhesive/cohesive cement fracture at } \\
\text { the crown }\end{array}$ & $\begin{array}{l}\text { In the crown lumen are cement residues but not the full thickness of the cement layer. The majority } \\
\text { of the cement is on the abutment. }\end{array}$ \\
\hline
\end{tabular}


Table 2 Pull-off forces in Newton (N) for each temporary cement per specimen before and after TC, fail outs were observed for Implantlink and Temp Bond NE with TC

\begin{tabular}{llllll}
\hline $\begin{array}{l}\text { Implantlink } \\
\text { (without TC) }\end{array}$ & $\begin{array}{l}\text { Harvard } \\
\text { (without TC) }\end{array}$ & $\begin{array}{l}\text { Temp Bond NE } \\
\text { (without TC) }\end{array}$ & $\begin{array}{l}\text { Implantlink } \\
\text { (with TC) }\end{array}$ & $\begin{array}{l}\text { Harvard } \\
\text { (with TC) }\end{array}$ & $\begin{array}{l}\text { Temp Bond NE } \\
\text { (with TC) }\end{array}$ \\
\hline 112.47 & 19.95 & 53.81 & 19.3 & 5.18 & 10.9 \\
78.18 & 42.15 & 50.74 & 48.9 & 14.1 & 9.52 \\
177.26 & 54.24 & 24.6 & 23.9 & 9.03 & 16.5 \\
109.52 & 53.97 & 89.34 & 11.1 & 27.6 & 30.1 \\
116.35 & 36.31 & 67.03 & 14.1 & 11.2 & 40.1 \\
106.89 & 26.51 & 82.89 & 8.56 & 42 & 4.47 \\
33.4 & 59.05 & 58.12 & 26 & 28.5 & 6.36 \\
119.58 & 73.04 & 80.43 & & 7.14 & 3.4 \\
55.94 & 44.49 & 39.42 & & 3.48 & 25.6 \\
95.25 & 48.12 & 65.25 & & &
\end{tabular}

$(p<0.01$; Bonferroni's multiple comparisons test; IMP vs. TBNE). After TC, the pull-off forces of the three tested temporary cements were reduced. The pull-off forces measured for IMP were highest at $21.69 \pm 13.61 \mathrm{~N}$ (three fail outs). HAV showed pull-off forces of $17.38 \pm 12.77 \mathrm{~N}$, similar to TBNE with $16.97 \pm 12.36 \mathrm{~N}$ (two fail outs). Statistically significant results could not be demonstrated.

Specimens of the HAV group without TC predominantly showed type I fractures (Table 3, Fig. 6). This fracture type was characterised by individual cement residues on the abutment. Type II fractures of this group were characterised by small cement residues in the area of the abutment shoulder. Types III and IV fractures were each represented once. The same four fracture types were also identified in the group with TC (Table 3) ( $p=0.2440$ in chi-square test of independence without vs. with TC).

TBNE specimens without TC showed mainly type III fractures (Table 3, Fig. 6). These showed differently imprinted cement residues on the abutment and inside the superstructure. Types II and V fractures were detected once each. The specimens with TC showed four fracture types (Table 3, Fig. 6) $(p=0.6849$ in chi-square test of independence without vs. with TC). Five type III fractures represent the most common fracture type. Types II, IV and V fractures were detected once each (Table 3, Fig. 6). For type $\mathrm{V}$ fractures, it is typical to find cement residues in the crown lumen, but the main part of the cement is on the abutment.

Without TC, the fracture mode analysis for IMP showed a similar distribution of fracture types I, II and III (Fig. 7). After TC, IMP showed a reduction of types I and III fractures $(p=0.7286$ in chi-square test of independence without vs. with TC) (Table 3, Fig. 6).

\section{Discussion}

In the present study, retention forces for the three tested temporary cements differed. Therefore, the first null

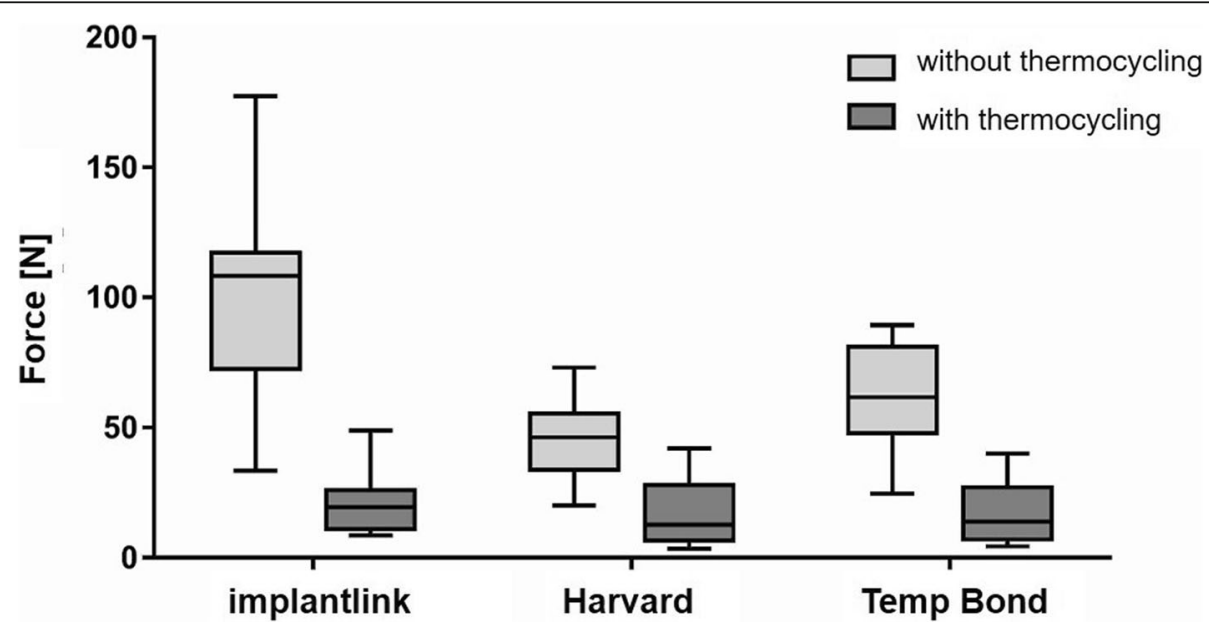

Fig. 5 Decementation load for the three tested cements (mean values with standard deviation) 
Table 3 Number of specimens regarding the fracture mode for each temporary cement

\begin{tabular}{|c|c|c|c|c|c|}
\hline Cement & $\begin{array}{l}\text { Adhesive cement } \\
\text { fracture on the } \\
\text { abutment (I) }\end{array}$ & $\begin{array}{l}\text { Adhesive/cohesive cement } \\
\text { fracture on the abutment (II) }\end{array}$ & $\begin{array}{l}\text { Cohesive } \\
\text { cement } \\
\text { fracture (III) }\end{array}$ & $\begin{array}{l}\text { Adhesive cement } \\
\text { fracture at the crown } \\
\text { (IV) }\end{array}$ & $\begin{array}{l}\text { Adhesive/cohesive } \\
\text { cement fracture at the } \\
\text { crown (V) }\end{array}$ \\
\hline $\begin{array}{l}\text { Implantlink } \\
\text { without TC }\end{array}$ & 3 & 3 & 4 & 0 & 0 \\
\hline $\begin{array}{l}\text { Implantlink } \\
\text { with TC }\end{array}$ & 1 & 3 & 3 & 0 & 0 \\
\hline $\begin{array}{l}\text { Harvard } \\
\text { without TC }\end{array}$ & 5 & 3 & 1 & 1 & 0 \\
\hline $\begin{array}{l}\text { Harvard with } \\
\text { TC }\end{array}$ & 1 & 5 & 3 & 1 & 0 \\
\hline $\begin{array}{l}\text { Temp Bond } \\
\text { NE without } \\
\text { TC }\end{array}$ & 0 & 1 & 8 & 0 & 1 \\
\hline $\begin{array}{l}\text { Temp Bond } \\
\text { NE with TC }\end{array}$ & 0 & 1 & 5 & 1 & 1 \\
\hline
\end{tabular}

hypothesis must be rejected since the objective of this study was to demonstrate homogeneous retention values of the three cements tested. Other studies also showed heterogeneous results regarding the retentive strength of different cements [5, 21-39]. Therefore, some studies published guidelines for clinicians since no cement served for all demands [40, 41]. Furthermore the retentive strength was very heterogeneous in the individual material classes and therefore not comparable [40].

The fracture modes of the three tested temporary cements after TC differ in the present study. As a consequence, the second null hypothesis must be rejected as well. The chi-square test did not show significant correlations. The fracture mode allows one to draw conclusions about the removability of cement residues when crown removal is necessary or when the crown detaches itself and re-cementing is required [42]. However, the fracture mode analysis provides information that influences the cement selection [42]. Cement residues in the crown lumen are easily removed by blasting with $\mathrm{Al}_{2} \mathrm{O}_{3}$ and improve the retention of the superstructure $[10,43$, 44]. Therefore, fractures of types I and II, which were predominantly detected at IMP and HAV, can be assessed as positive [42]. In these fracture types, the majority of the cement is in the crown lumen, and the abutment is largely free of cement. The screw access in the abutment is free, and the abutment is not further damaged when trying to remove cement residues [42].

To bring the results closer to clinical conditions, an artificial ageing process was conducted. Test specimens were

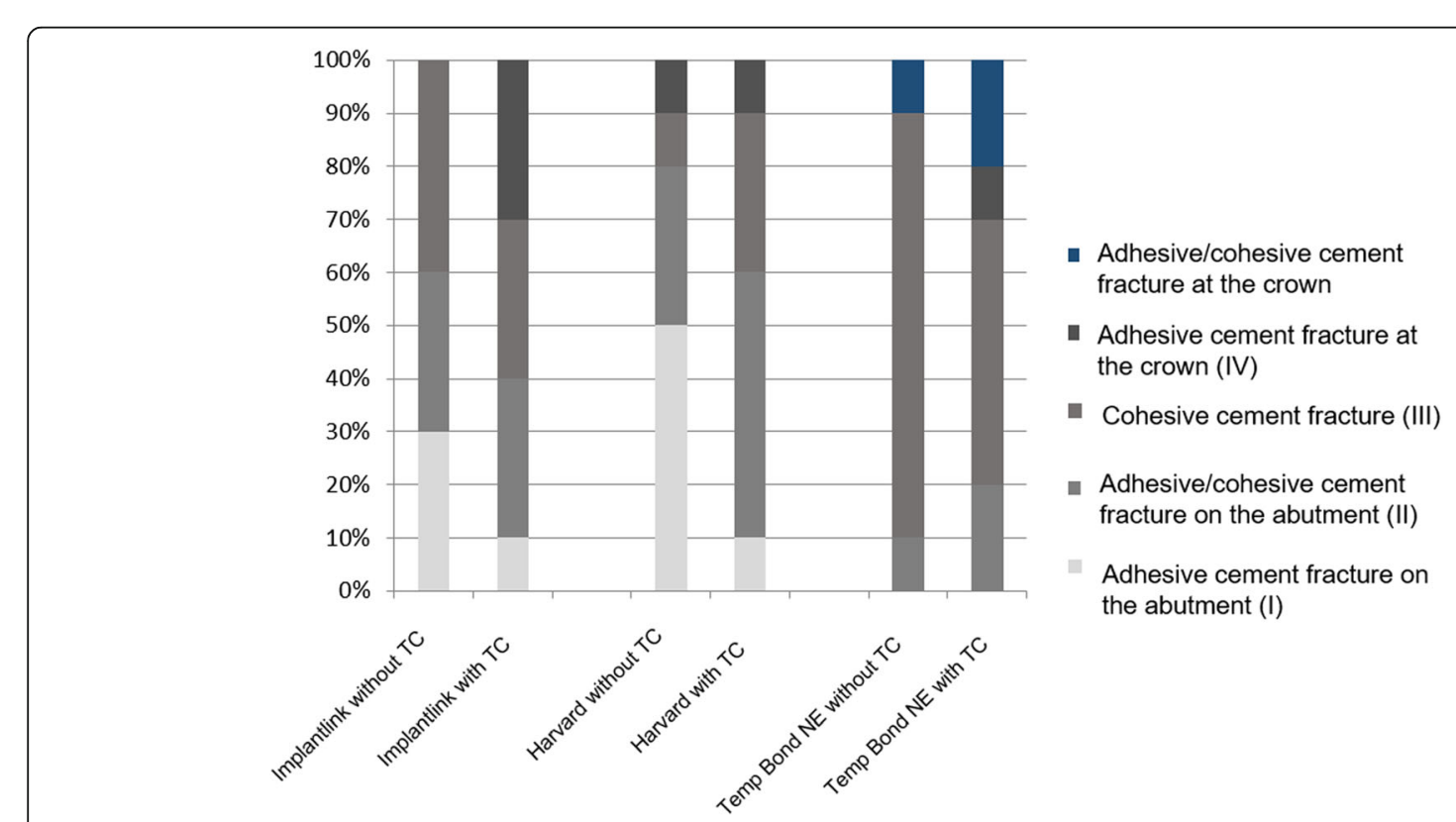

Fig. 6 Fracture mode analysis of the tested temporary cements 


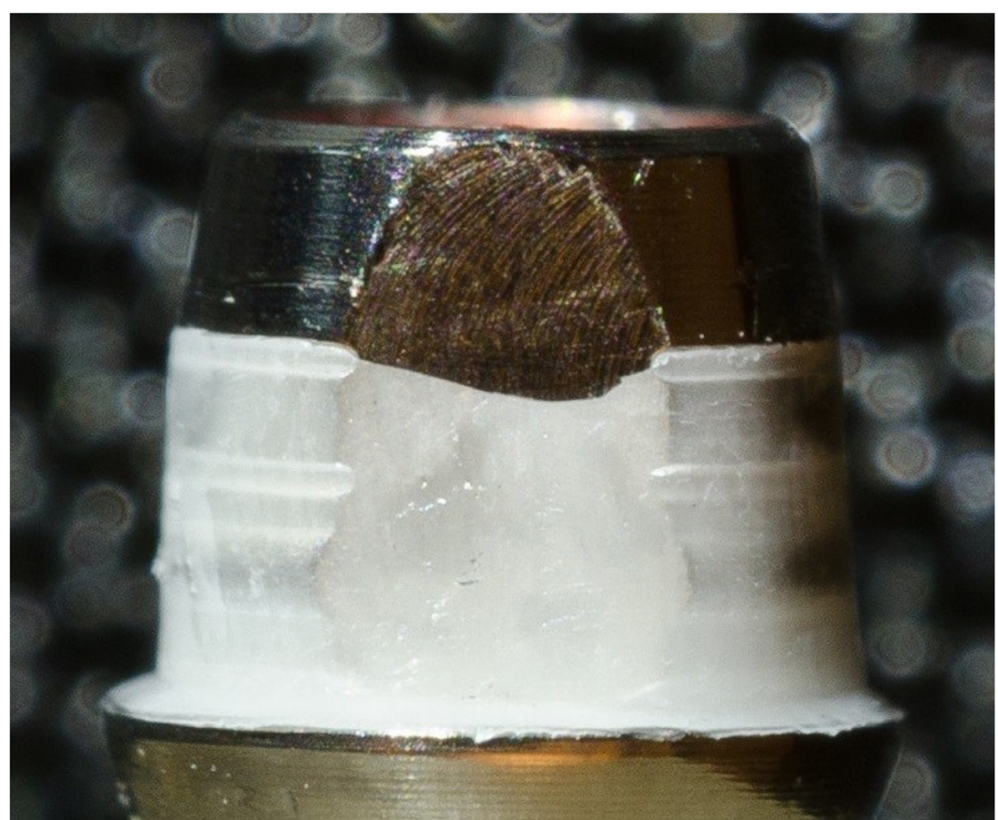

Fig. 7 Cohesive cement fracture (type III; implantlink semi Forte)

stored for $24 \mathrm{~h}$ in distilled water and half of the test specimens of each group were subjected to a thermocycling process. The number of cycles was chosen based on other studies that have addressed this issue [21, 23, 45]. Gale and Darvell proposed that 10,000 cycles might represent approximately 1 year of in vivo conditions, with 20 to 50 cycles considered equivalent to a single day [46]. It can be concluded that 6000 cycles correspond to about 7 months of clinical use. The water storage was used to simulate oral cavity moisture. During water storage, moisture absorption occurs in the cement gap, which causes an increase in volume of the cement $[37,38]$. In addition, water storage leads to a wash-out effect within the cement structure and thus simulates the ageing process of the cements in the oral cavity [5, 10,37]. This artificial ageing can be enhanced by TC and influences the retention forces of the different cements very differently depending on the number of cycles [5, 37, 38]. Thermocycling is an artificial ageing in vitro and imitate temperature changes as they occur naturally intraorally. However, thermocycling can be used to mimic the clinical situation, but it has no relevance for direct comparisons to in vivo conditions [19]. Some studies have performed thermocycling in order to evaluate retention forces of the cements tested [5, 20-38]. For temporary cements, a considerable decrease in regards to the pull-off forces has been proven to be caused by the artificial ageing process [22]. A direct transfer of the results obtained from the present in vitro study to the clinical situation should be viewed critically.

Regarding the abutment geometry, significantly shorter abutments $(3 \mathrm{~mm})$ were used in this study compared to other studies regarding this topic [10, 47]. However, abutment heights of $5.5 \mathrm{~mm}$ or more are not always clinically feasible. Despite the significantly lower abutment height, the measured retention forces of the three cements were in a range that the cements also showed in other publications $[5,48]$. Results by Safari et al. already showed that the abutment height has less influence on retention than the abutment geometry [42]. In contrast, Abbo et al. showed that a reduction of the abutment height by $1 \mathrm{~mm}$ significantly reduces the retention force [49]. This was also confirmed by Sarfaraz et al. [50]. Lewinstein et al. reported that the retention forces of temporary cemented crowns on implant abutments can be significantly increased by circumferential grooves [29]. The abutments used in the present study were provided with two grooves. Pull-off forces showed values as published by other working groups despite the low abutment height of $3 \mathrm{~mm}$ [48].

In the present study, the cement gap size was set to 30 $\mu \mathrm{m}$. So far, mostly different cement film thicknesses have been compared in different studies [34, 40, 51-59]. Ebert et al. showed that increasing the cement gap from 30 to $60 \mu \mathrm{m}$ had a detrimental effect on the durability of cements [56]. On the other hand, Wu and Wilson showed that for optimal seating, the cement gap should be larger than $30 \mu \mathrm{m}$ [60]. Mehl et al. showed that the pull-off force of implant-supported crowns is significantly worsened by an increase of the cement gap from 10 to $50 \mu \mathrm{m}$ [2]. Some authors assessed low cement gap thicknesses as an advantage in terms of pull-off forces $[2,61]$. Most studies recommended a cement thickness 
of 20 to $40 \mu \mathrm{m}$, as this size generates complete seating of the restoration [62-65]. Gultekin showed that increasing the cement gap from 20 to $40 \mu \mathrm{m}$ for lower strength cements such as TBNE did not significantly increase retention [40]. For this reason, a cement gap of $30 \mu \mathrm{m}$ was selected in the present study, in which semipermanent cements were investigated with regard to their retentive strength.

From the generated data, it can be concluded that cements specially developed for the temporary cementation of superstructures on implant abutments do not differ from the conventional temporary cement TBNE. The risk of decementation seems to increase with temporary cements. Therefore, temporary cementation of zirconia crowns on titanium abutments is recommended reluctantly. However, cements that have been specially developed for temporary cementation on implant abutments are more likely to be used when retrievability of the superstructure is considered likely.

\section{Conclusions}

The present study showed that the influence of artificial ageing is important for imitating clinical conditions regarding retention forces. IMP showed the highest pulloff forces under the chosen test conditions. All three temporary luting agents showed significantly lower retention forces after thermocycling. Because of the easy cement removal in the crown lumen, the dominance of adhesive cement fractures on the abutment and adhesive/cohesive cement fractures on the abutment with HAV appear to be an advantage in case of recementation of the superstructure and thus gives clinicians advice which cement to use for different requirements.

\section{Abbreviations}

HAV: Harvard Implant Semi-permanent; IMP: Implantlink semi Forte: TBNE: Temp Bond NE; TC: Thermocycling

\section{Acknowledgements}

Prof. Dr. Jeremias Hey is acknowledged for his valuable support during the study and the professional proofreading of the final manuscript.

\section{Authors' contributions}

The present study was conducted by Dr. Felix Dähne. Dr. Elisabeth Prause translated, formatted and structured the review. All authors read and approved the final manuscript.

\section{Funding}

Not applicable

\section{Availability of data and materials}

All data generated or analysed during this study are included in this published article (and its supplementary information files).

\section{Declarations}

Ethics approval and consent to participate

Not applicable

\section{Consent for publication}

Not applicable

\section{Competing interests}

Felix Dähne, Heike Meißner, Klaus Böning, Christin Arnold, Ralf Gutwald and Elisabeth Prause declare that they have no competing interests.

\section{Author details}

${ }^{1}$ Department of Oral and Plastic Maxillofacial Surgery, University Hospital Halle, Martin Luther University Halle-Wittenberg, Ernst-Grube-Str. 40, 06120 Halle, Germany. ${ }^{2}$ Department of Prosthodontics, Carl Gustav Carus Faculty of Medicine, University of Technology, Fetscherstrasse 74, 01307 Dresden, Germany. ${ }^{3}$ Department of Prosthodontics, School of Dental Medicine, Martin-Luther-University, Magdeburger Str. 16, 06112 Halle, Germany. ${ }^{4}$ Faculty of Medicine/Dentistry, Danube Private University (DPU), Steiner Landstraße 124, 3500 Krems-Stein, Austria. ${ }^{5}$ Department of Prosthodontics, Geriatric Dentistry and Craniomandibular Disorders, University Charité Berlin, Aßmannshauser Str. 4-6, 14197 Berlin, Germany.

Received: 11 February 2021 Accepted: 22 April 2021

Published online: 20 July 2021

\section{References}

1. Mehl C, Harder S, Wolfart M, Kern M, Wolfart S. Retrievability of implantretained crowns following cementation. Clin Oral Implants Res. 2008;19(12): 1304-11. https://doi.org/10.1111/j.1600-0501.2008.01587.x.

2. Mehl C, Harder S, Steiner M, Vollrath $O$, Kern M. Influence of cement film thickness on the retention of implant-retained crowns. J Prosthodont. 2013; 22(8):618-25. https://doi.org/10.1111/jopr.12058.

3. Chee W, Felton DA, Johnson PF, Sullivan DY. Cemented versus screwretained implant prostheses: which is better? Int J Oral Maxillofac Implants. 1999;14(1):137-41.

4. Thoma DS, Wolleb K, Bienz SP, Wiedemeier D, Hammerle CHF, Sailer I. Early histological, microbiological, radiological, and clinical response to cemented and screw-retained all-ceramic single crowns. Clin Oral Implants Res. 2018; 29(10):996-1006. https://doi.org/10.1111/clr.13366.

5. Schiessl C, Schaefer L, Winter C, Fuerst J, Rosentritt M, Zeman F, et al. Factors determining the retentiveness of luting agents used with metaland ceramic-based implant components. Clin Oral Investig. 2013;17(4):117990. https://doi.org/10.1007/s00784-012-0798-x.

6. Torrado E, Ercoli C, Al Mardini M, Graser GN, Tallents RH, Cordaro L. A comparison of the porcelain fracture resistance of screw-retained and cement-retained implant-supported metal-ceramic crowns. J Prosthet Dent. 2004;91(6):532-7. https://doi.org/10.1016/j.prosdent.2004.03.014.

7. Weber HP, Kim DM, Ng MW, Hwang JW, Fiorellini JP. Peri-implant soft-tissue health surrounding cement- and screw-retained implant restorations: a multi-center, 3-year prospective study. Clin Oral Implants Res. 2006;17(4): 375-9. https://doi.org/10.1111/j.1600-0501.2005.01232.x.

8. Duyck J, Naert I. Influence of prosthesis fit and the effect of a luting system on the prosthetic connection preload: an in vitro study. Int J Prosthodont. 2002;15(4):389-96

9. Pietrabissa R, Gionso L, Quaglini V, Di Martino E, Simion M. An in vitro study on compensation of mismatch of screw versus cement-retained implant supported fixed prostheses. Clin Oral Implants Res. 2000;11(5):448-57. https://doi.org/10.1034/j.1600-0501.2000.011005448.x.

10. Rodiger M, Rinke S, Ehret-Kleinau F, Pohlmeyer F, Lange K, Burgers R, et al. Evaluation of removal forces of implant-supported zirconia copings depending on abutment geometry, luting agent and cleaning method during re-cementation. J Adv Prosthodont. 2014;6(3):233-40. https://doi. org/10.4047/jap.2014.6.3.233.

11. Heinemann F, Mundt T, Biffar R. Retrospective evaluation of temporary cemented, tooth and implant supported fixed partial dentures. J Craniomaxillofac Surg. 2006;34(Suppl 2):86-90. https://doi.org/10.1016/S101 0-5182(06)60019-X.

12. Dixon DL, Breeding LC, Lilly KR. Use of luting agents with an implant system: Part II. J Prosthet Dent. 1992;68(6):885-90. https://doi.org/10.1016/ 0022-3913(92)90544-K

13. Breeding LC, Dixon DL, Bogacki MT, Tietge JD. Use of luting agents with an implant system: Part I. J Prosthet Dent. 1992;68(5):737-41. https://doi.org/1 0.1016/0022-3913(92)90194-F.

14. Covey DA, Kent DK, St Germain HA Jr, Koka S. Effects of abutment size and luting cement type on the uniaxial retention force of implant-supported crowns. J Prosthet Dent. 2000;83(3):344-8. https://doi.org/10.1016/S0022-3 913(00)70138-7. 
15. Di Felice R, Rappelli G, Camaioni E, Cattani M, Meyer JM, Belser UC. Cementable implant crowns composed of cast superstructure frameworks luted to electroformed primary copings: an in vitro retention study. Clin Oral Implants Res. 2007;18(1):108-13. https://doi.org/10.1111/j.1600-0501.2 006.01299.x

16. Dudley JE, Richards LC, Abbott JR. Retention of cast crown copings cemented to implant abutments. Aust Dent J. 2008;53(4):332-9. https://doi. org/10.1111/j.1834-7819.2008.00075.x.

17. Kaar D, Oshida Y, Andres CJ, Barco MT, Platt JA. The effect of fatigue damage on the force required to remove a restoration in a cement-retained implant system. J Prosthodont. 2006;15(5):289-94. https://doi.org/10.1111/j.1 532-849X.2006.00126.X

18. Garg P, Gupta G, Prithviraj DR, Pujari M. Retentiveness of various luting agents used with implant-supported prostheses: a preliminary in vitro study. Int J Prosthodont. 2013;26(1):82-4. https://doi.org/10.11607/ijp.2572.

19. Alvarez-Arenal A, Gonzalez-Gonzalez I, Pines-Hueso J. deLlanos-Lanchares H, del Rio Highsmith J. The effect of compressive cyclic loading on the retention of cast single crowns cemented to implant abutments. Int J Prosthodont. 2016;29(1):80-2. https://doi.org/10.11607/ijp.4355.

20. Blender SM, Mellinghoff J, Groller SB, Schnutenhaus S, Kuhn K, Luthardt RG, et al. Effects of abutment height and type of cements on bond strength of monolithic zirconia single crowns luted to one-piece zirconia implants. Int J Prosthodont. 2021

21. Naumova EA, Roth F, Geis B, Baulig C, Arnold WH, Piwowarczyk A. Influence of luting materials on the retention of cemented implant-supported crowns: an in vitro study. Materials (Basel). 2018;11(10).

22. Pan $\mathrm{YH}$, Lin CK. The effect of luting agents on the retention of dental implant-supported crowns. Chang Gung Med J. 2005;28(6):403-10.

23. Guler U, Budak Y, Queiroz JRC, Ozcan M. Dislodgement resistance of zirconia copings cemented onto zirconia and titanium abutments. Implant Dent. 2017;26(4):510-5. https://doi.org/10.1097//D.0000000000000589.

24. Gumus $\mathrm{HO}$, Kurtulus IL, Kuru E. Evaluation and comparison of the film thicknesses of six temporary cements before and after thermal cycling. Niger J Clin Pract. 2018;21(12):1656-61. https://doi.org/10.4103/njcp.njcp_382_17.

25. Guncu MB, Cakan U, Canay S. Comparison of 3 luting agents on retention of implant-supported crowns on 2 different abutments. Implant Dent. 2011; 20(5):349-53. https://doi.org/10.1097//D.0b013e318225f68e.

26. Kokubo Y, Kano T, Tsumita M, Sakurai S, Itayama A, Fukushima S. Retention of zirconia copings on zirconia implant abutments cemented with provisional luting agents. J Oral Rehabil. 2010;37(1):48-53. https://doi.org/1 0.1111/j.1365-2842.2009.02013.x.

27. Kurt M, Kulunk T, Ural C, Kulunk S, Danisman S, Savas S. The effect of different surface treatments on cement-retained implant-supported restorations. J Oral Implantol. 2013;39(1):44-51. https://doi.org/10.1563/AA ID-JOI-D-10-00151.

28. Lennartz A, Dohmen A, Bishti S, Fischer H, Wolfart S. Retrievability of implantsupported zirconia restorations cemented on zirconia abutments. J Prosthet Dent. 2018;120(5):740-6. https://doi.org/10.1016/j.prosdent.2018.01.011.

29. Lewinstein I, Block L, Lehr Z, Ormianer Z, Matalon S. An in vitro assessment of circumferential grooves on the retention of cement-retained implantsupported crowns. J Prosthet Dent. 2011;106(6):367-72. https://doi.org/10.1 016/S0022-3913(11)60149-2.

30. Mehl C, Harder S, Schwarz D, Steiner M, Vollrath O, Kern M. In vitro influence of ultrasonic stress, removal force preload and thermocycling on the retrievability of implant-retained crowns. Clin Oral Implants Res. 2012; 23(8):930-7. https://doi.org/10.1111/j.1600-0501.2011.02236.x.

31. Mehl C, Ali S, El Bahra S, Harder S, Vollrath O, Kern M. Is there a correlation between tensile strength and retrievability of cemented implant-retained crowns using artificial aging? Int J Prosthodont. 2016;29(1):83-90. https:// doi.org/10.11607/ijp.4317.

32. Nejatidanesh F, Savabi O, Shahtoosi M. Retention of implant-supported zirconium oxide ceramic restorations using different luting agents. Clin Oral Implants Res. 2013;24(Suppl A100):20-4.

33. Nejatidanesh F, Savabi O, Savabi G, Razavi M. Effect of cleaning methods on retentive values of saliva-contaminated implant-supported zirconia copings. Clin Oral Implants Res. 2018;29(5):530-6. https://doi.org/10.1111/clr.13150.

34. Pan YH, Ramp LC, Lin CK, Liu PR. Retention and leakage of implantsupported restorations luted with provisional cement: a pilot study. J Oral Rehabil. 2007;34(3):206-12. https://doi.org/10.1111/j.1365-2842.2006.01673.x.

35. Pitta J, Bijelic-Donova J, Burkhardt F, Fehmer V, Narhi T, Sailer I. Temporary implant-supported single crowns using titanium base abutments: an in vitro study on bonding stability and pull-out forces. Int J Prosthodont. 2020;33(5): 546-52. https://doi.org/10.11607/ijp.6778.

36. Pitta J, Burkhardt F, Mekki M, Fehmer V, Mojon P, Sailer I. Effect of airborneparticle abrasion of a titanium base abutment on the stability of the bonded interface and retention forces of crowns after artificial aging. J Prosthet Dent. 2020. https://doi.org/10.1016/j.prosdent.2020.06.013.

37. Rohr N, Balmer M, Muller JA, Martin S, Fischer J. Chewing simulation of zirconia implant supported restorations. J Prosthodont Res. 2019;63(3):3617. https://doi.org/10.1016/j.jpor.2019.02.002.

38. Rues S, Fugina M, Rammelsberg P, Kappel S. Cemented single crown retention on dental implants: an in vitro study. Int J Prosthodont. 2017;30(2): 133-5. https://doi.org/10.11607/ijp.4994.

39. Sellers K, Powers JM, Kiat-Amnuay S. Retentive strength of implantsupported CAD-CAM lithium disilicate crowns on zirconia custom abutments using 6 different cements. J Prosthet Dent. 2017;117(2):247-52. https://doi.org/10.1016/j.prosdent.2016.06.014.

40. Gultekin P, Gultekin BA, Aydin M, Yalcin S. Cement selection for implantsupported crowns fabricated with different luting space settings. J Prosthodont. 2013;22(2):112-9. https://doi.org/10.1111/j.1532-849X.2012. 00912.x.

41. Sheets $\mathrm{J}$, Wilcox $\mathrm{C}$, Wilwerding T. Cement selection for cement-retained crown technique with dental implants. J Prosthodont. 2008;17(2):92-6. https://doi.org/10.1111/j.1532-849X.2007.00262.x.

42. Safari S, Hosseini Ghavam F, Amini P, Yaghmaei K. Effects of abutment diameter, luting agent type, and re-cementation on the retention of implant-supported CAD/CAM metal copings over short abutments. J Adv Prosthodont. 2018;10(1):1-7. https://doi.org/10.4047/jap.2018.10.1.1.

43. Chintapalli RK, Mestra Rodriguez A, Garcia Marro F, Anglada M. Effect of sandblasting and residual stress on strength of zirconia for restorative dentistry applications. J Mech Behav Biomed Mater. 2014;29:126-37. https:// doi.org/10.1016/j.jmbbm.2013.09.004.

44. Kern M. Bonding to oxide ceramics-laboratory testing versus clinical outcome. Dent Mater. 2015;31(1):8-14. https://doi.org/10.1016/j.dental.2014. 06.007 .

45. Nejatidanesh F, Savabi O, Ebrahimi M, Savabi G. Retentiveness of implantsupported metal copings using different luting agents. Dent Res J (Isfahan). 2012;9(1):13-8. https://doi.org/10.4103/1735-3327.92921.

46. Gale MS, Darvell BW. Thermal cycling procedures for laboratory testing of dental restorations. J Dent. 1999;27(2):89-99. https://doi.org/10.1016/S03005712(98)00037-2.

47. Carnaggio TV, Conrad R, Engelmeier RL, Gerngross P, Paravina R, Perezous L, et al. Retention of CAD/CAM all-ceramic crowns on prefabricated implant abutments: an in vitro comparative study of luting agents and abutment surface area. J Prosthodont. 2012;21(7):523-8. https://doi.org/10.1111/j.1532849X.2012.00847X.

48. Rohr N, Brunner S, Martin S, Fischer J. Influence of cement type and ceramic primer on retention of polymer-infiltrated ceramic crowns to a one-piece zirconia implant. J Prosthet Dent. 2018;119(1):138-45. https://doi.org/10.101 6/j.prosdent.2017.02.002.

49. Abbo B, Razzoog ME, Vivas J, Sierraalta M. Resistance to dislodgement of zirconia copings cemented onto titanium abutments of different heights. J Prosthet Dent. 2008;99(1):25-9. https://doi.org/10.1016/S0022-3913 (08)60005-0.

50. Sarfaraz H, Hassan A, Shenoy KK, Shetty M. An in vitro study to compare the influence of newer luting cements on retention of cement-retained implant-supported prosthesis. J Indian Prosthodont Soc. 2019;19(2):166-72. https://doi.org/10.4103/jips.jips_235_18.

51. Santosa RE, Martin W, Morton D. Effects of a cementing technique in addition to luting agent on the uniaxial retention force of a single-tooth implant-supported restoration: an in vitro study. Int J Oral Maxillofac Implants. 2010;25(6):1145-52.

52. Pan YH, Ramp LC, Lin CK, Liu PR. Comparison of 7 luting protocols and their effect on the retention and marginal leakage of a cement-retained dental implant restoration. Int J Oral Maxillofac Implants. 2006;21(4):587-92.

53. Squier RS, Agar JR, Duncan JP, Taylor TD. Retentiveness of dental cements used with metallic implant components. Int J Oral Maxillofac Implants. 2001; 16(6):793-8.

54. Michalakis K, Pissiotis AL, Kang K, Hirayama H, Garefis PD, Petridis H. The effect of thermal cycling and air abrasion on cement failure loads of 4 provisional luting agents used for the cementation of implant-supported fixed partial dentures. Int J Oral Maxillofac Implants. 2007;22(4):569-74. 
55. Akca K, Iplikcioglu H, Cehreli MC. Comparison of uniaxial resistance forces of cements used with implant-supported crowns. Int J Oral Maxillofac Implants. 2002;17(4):536-42.

56. Ebert A, Hedderich J, Kern M. Retention of zirconia ceramic copings bonded to titanium abutments. Int J Oral Maxillofac Implants. 2007;22(6):921-7.

57. Mansour A, Ercoli C, Graser G, Tallents R, Moss M. Comparative evaluation of casting retention using the III solid abutment with six cements. Clin Oral Implants Res. 2002;13(4):343-8. https:/doi.org/10.1034/j.1600-0501.2002.130401.x.

58. Rosentritt M, Steiger D, Behr M, Handel G, Kolbeck C. Influence of substructure design and spacer settings on the in vitro performance of molar zirconia crowns. J Dent. 2009;37(12):978-83. https://doi.org/10.1016/j. jdent.2009.08.003.

59. Carter SM, Wilson PR. The effect of die-spacing on crown retention. Int J Prosthodont. 1996;9(1):21-9.

60. Wu JC, Wilson PR. Optimal cement space for resin luting cements. Int J Prosthodont. 1994;7(3):209-15.

61. Kim Y, Yamashita J, Shotwell JL, Chong KH, Wang HL. The comparison of provisional luting agents and abutment surface roughness on the retention of provisional implant-supported crowns. J Prosthet Dent. 2006;95(6):450-5. https://doi.org/10.1016/j.prosdent.2006.03.020.

62. Emtiaz S, Goldstein G. Effect of die spacers on precementation space of complete-coverage restorations. Int J Prosthodont. 1997:10(2):131-5.

63. Webb EL, Murray HV, Holland GA, Taylor DF. Effects of preparation relief and flow channels on seating full coverage castings during cementation. J Prosthet Dent. 1983;49(6):777-80. https:/doi.org/10.1016/0022-3913(83)90347-5.

64. Akashia AE, Francischone CE, Tokutsune E, da Silva W Jr. Effects of different types of temporary cements on the tensile strength and marginal adaptation of crowns on implants. J Adhes Dent. 2002;4(4):309-15.

65. Jacob SJ, Hegde C, Prasad KD, Shetty M. An in vitro study to evaluate the effect of storage time and application of subsequent layers on the variation in thickness of three commercially available die spacers. Indian J Dent Res. 2010;21(1):92-7. https://doi.org/10.4103/0970-9290.62822.

\section{Publisher's Note}

Springer Nature remains neutral with regard to jurisdictional claims in published maps and institutional affiliations.

\section{Submit your manuscript to a SpringerOpen ${ }^{\circ}$ journal and benefit from:}

- Convenient online submission

- Rigorous peer review

- Open access: articles freely available online

High visibility within the field

- Retaining the copyright to your article

Submit your next manuscript at $\boldsymbol{\nabla}$ springeropen.com 